\title{
Coseismic changes in groundwater level during the 2018 Hokkaido Eastern Iburi earthquake
}

\author{
Tomo Shibata ${ }^{*} \mathbb{E}$, Ryo Takahashi ${ }^{2}$, Hiroaki Takahashi ${ }^{3}$,Takanori Kagoshima ${ }^{4}$, Naoto Takahata ${ }^{4}$, Yuji Sano ${ }^{4}$ \\ and Daniele L. Pinti ${ }^{5}$
}

\begin{abstract}
Six wells were continuously monitored in Hokkaido, northern Japan, to relate groundwater level changes to regional seismic activity. Groundwater level changes following the 2018 Hokkaido Eastern Iburi earthquake were detected in three of the six wells, even though they are located hundreds of kilometers from the epicenter. The groundwater level changes are qualitatively consistent with the volumetric strain induced by the earthquake. We analyzed groundwater level responses to the $\mathrm{M}_{2}$ tidal constituent before and after the earthquake, but related changes in amplitude and phase shifts remained within the usual variation. Observed coseismic change was explained by the response to the $\mathrm{M}_{2}$ tidal constituent component and the calculated volumetric strain for one of the wells, where groundwater level decreased. The observed change in the other two was found to be much greater than the corresponding estimates of the volumetric strain.
\end{abstract}

Keywords: Groundwater level, Coseismic change, 2018 Hokkaido Eastern Iburi earthquake, Tidal response

\section{Introduction}

Numerous case studies describe changes in groundwater level in boreholes and wells associated with earthquakes (e.g., Igarashi and Wakita 1991; Roeloffs 1996; Quilty and Roeloffs 1997; Akita and Matsumoto 2001, 2004; Manga and Wang 2007). These changes can be explained by several processes, such as the response of pore pressure to coseismic strain changes (Wakita 1975; Muir-Wood and King 1993), changes in permeability due to seismic waves (Rojstaczer et al. 1995; Wang et al. 2004; Elkhoury et al. 2006; Kinoshita et al. 2015), and fluid and gas movements in cracks or crustal fractures (Sibson and Rowland 2003; Matsumoto and Roeloffs 2003). Sometimes, these changes are even measurable in wells located thousands of kilometers from the earthquake epicenter (Brodsky et al. 2003; Montgomery and Manga 2003; Shi et al. 2015).

The 2018 Hokkaido Eastern Iburi earthquake, with a magnitude of 6.7, occurred in the central and eastern Iburi region, Hokkaido, Japan, on September 6th 2018 at 03:07 Japan Standard Time (JST) (Japan Meteorological Agency 2018a). The hypocenter was located at a depth of $37 \mathrm{~km}$, which may correspond to a complex crustal to upper mantle structure within the Hidaka arc-arc collision system (Takahashi and Kimura 2019). The earthquake occurred on a reverse fault with an ENE-WSW compression axis. Here, we report changes in groundwater levels associated with the 2018 Hokkaido Eastern Iburi earthquake, and the responses of the groundwater level to the $\mathrm{M}_{2}$ tidal constituent before and after the earthquake.

\footnotetext{
${ }^{*}$ Correspondence: swn05-toshibat@bep.vgs.kyoto-u.ac.jp

${ }^{1}$ Institute for Geothermal Sciences, Graduate School of Science, Kyoto

University, Noguchibaru 3088, Beppu, Oita 874-0903, Japan

Full list of author information is available at the end of the article
}

\section{Springer Open}

(c) The Author(s) 2020. This article is licensed under a Creative Commons Attribution 4.0 International License, which permits use, sharing, adaptation, distribution and reproduction in any medium or format, as long as you give appropriate credit to the original author(s) and the source, provide a link to the Creative Commons licence, and indicate if changes were made. The images or other third party material in this article are included in the article's Creative Commons licence, unless indicated otherwise in a credit line to the material. If material is not included in the article's Creative Commons licence and your intended use is not permitted by statutory regulation or exceeds the permitted use, you will need to obtain permission directly from the copyright holder. To view a copy of this licence, visit http://creativeco mmons.org/licenses/by/4.0/. 


\section{Observation sites, data, and methods}

The Geological Survey of Hokkaido of the Hokkaido Research Organization monitors groundwater levels in six wells located in different regions of the Island of Hokkaido, Japan (Fig. 1). The wells were drilled to exploit hot spring water, but have not been used for this purpose in the past 20 years (Table 1 ). Well depths range between 120 and $1103 \mathrm{~m}$ below surface level. The corresponding aquifers, which are confined, are hosted by volcanic rocks and/or sedimentary rocks, and are barely affected by meteoric recharge, except for the shallow aquifer tapped by well ABT (Table 1). The fact that the wells are not

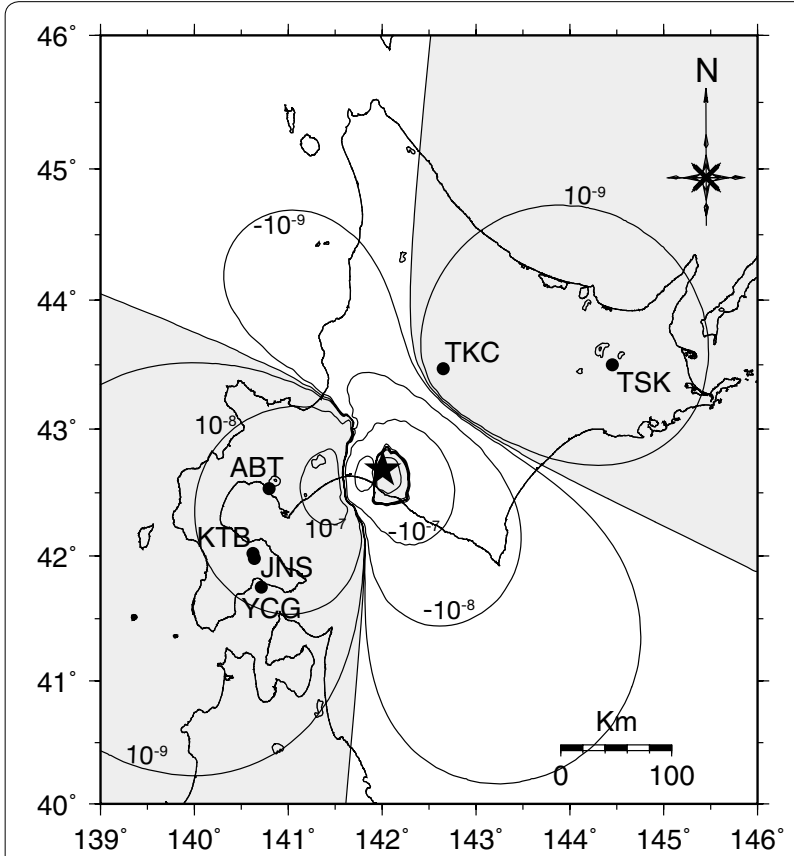

Fig. 1 Locations of the monitored observation wells (ABT, JNS, KTB, TKC, TSK, and YCG; solid circles) and the epicenter of the 2018 Hokkaido Eastern Iburi earthquake (solid star). Volumetric strain, indicated by contours extending from the epicenter, was calculated using the fault model of the earthquake (Geospatial Information Authority of Japan 2018). The gray area indicates tensile field perturbed by pumping or other anthropic actions allows them to be used to monitor possible changes in aquifer pore pressure caused by local crustal stress changes. Groundwater levels were measured at each monitored well using pressure gauges with a resolution of approximately $5-10 \mathrm{~mm}$, in $10 \mathrm{~min}$ intervals. Measurements were recorded on-site using data loggers (Kadec Series, Northone Co. Ltd.).

The measured groundwater levels are plotted along with the atmospheric pressure and rainfall from September 2017 to December 2018 in Fig. 2, although some data are missing for wells ABT, TKC, and TSK. We also measured the atmospheric pressure on TKC and TSK sites, but for the others wells, atmospheric pressure and rainfall data were from the nearest observation sites of the Automated Meteorological Data Acquisition System (AMeDAS) (Japan Meteorological Agency 2018b). We also plotted residual groundwater levels in Fig. 2 which removed effects of tidal and atmospheric components from observed groundwater levels by using the BAYTAPG tidal analysis software (Tamura et al. 1991). Changes in groundwater levels are all within $1 \mathrm{~m}$ except for wells $\mathrm{ABT}$ and JNS. We show the groundwater level changes during the earthquake in Fig. 3.

We calculated the volumetric strain change (Fig. 1) induced by the earthquake using the code of Okada (1992) and the fault model proposed for this seismic event (Geospatial Information Authority of Japan 2018). The wells for which groundwater level changes were observed are located in the area affected by the tensile change of the volumetric strain caused by the earthquake (Fig. 1). After the earthquake, step-like decreases in groundwater levels were detected for three of the wells (JNS, KTB and YCG; Fig. 3). This suggests that the changes in groundwater levels are qualitatively consistent with those of the volumetric strain (Koizumi et al. 2002).

The fluctuation in groundwater level is generally proportional to the applied strain of a tidal component, and the response of groundwater level to this component is

Table 1 Descriptions of the observation wells

\begin{tabular}{lllccc}
\hline Site & Location & & Depth $(\mathbf{m})$ & Screen depth $(\mathbf{m})$ \\
\cline { 2 - 5 } & Latitude $\left(^{\circ}\right)$ & Longitude $\left(^{\circ}\right)$ & Altitude $(\mathbf{m})$ & 120 & - \\
\hline ABT & 42.532 & 140.797 & 72.0 & 1103 & $570-1078$ \\
JNS & 41.980 & 140.638 & 169.0 & 974 & $638-947$ \\
KTB & 42.022 & 140.626 & 165.0 & 1000 & $476-1000$ \\
TKC & 43.472 & 142.650 & 670.2 & 1030 & $619-1030$ \\
TSK & 43.500 & 144.452 & 134.0 & 200 & $150-200$ \\
YCG & 41.753 & 140.415 & 6.0 & & \\
\hline
\end{tabular}




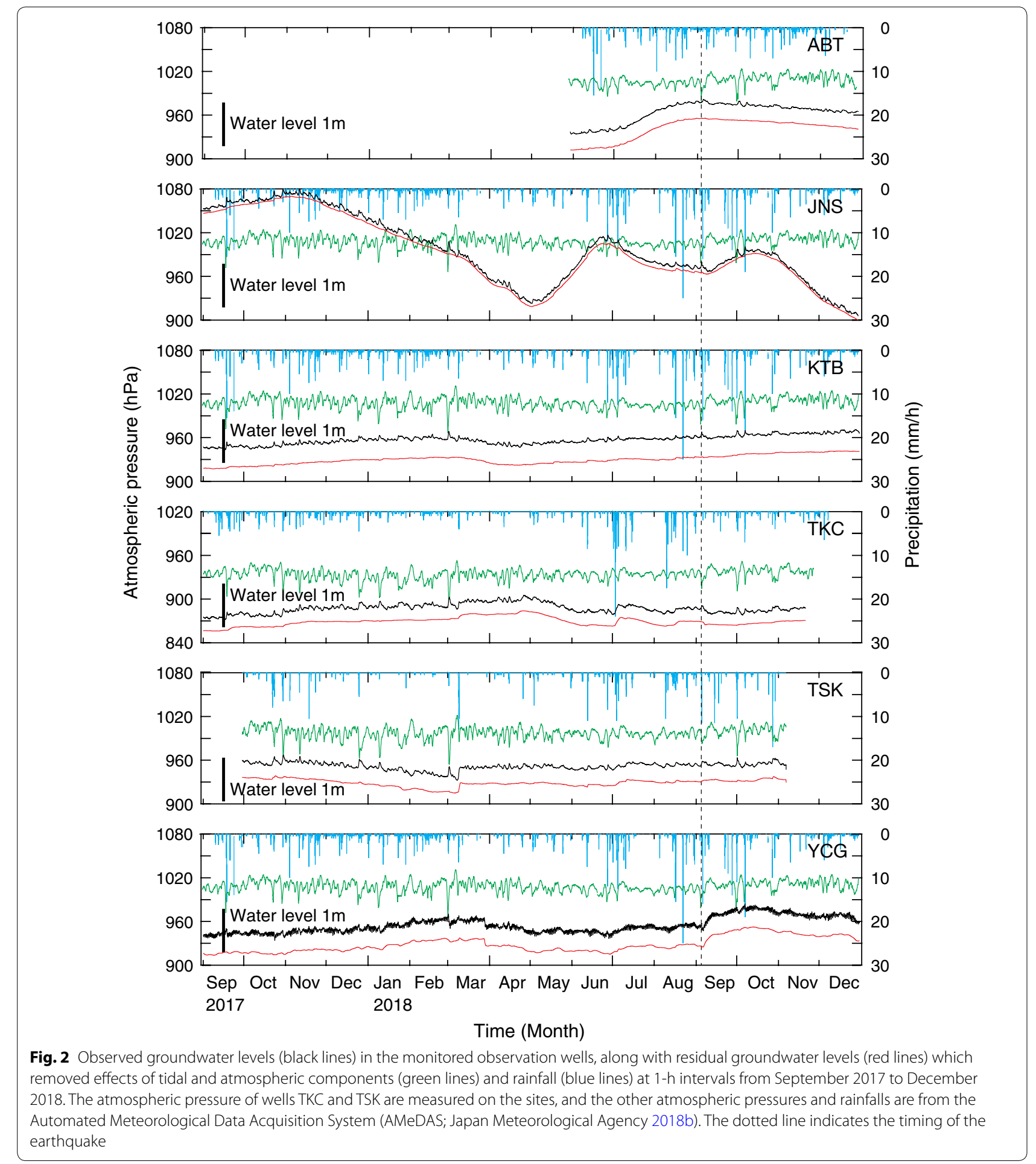

directly related to the poroelastic characteristics of the aquifer (i.e., Jacob 1940; Hsieh et al. 1987; Wang 2000). If the aquifer is confined, the relationship between the change in groundwater level, $\Delta h$, and the volumetric strain, $\Delta \varepsilon$, is represented by the relationship (Wang 2000): 


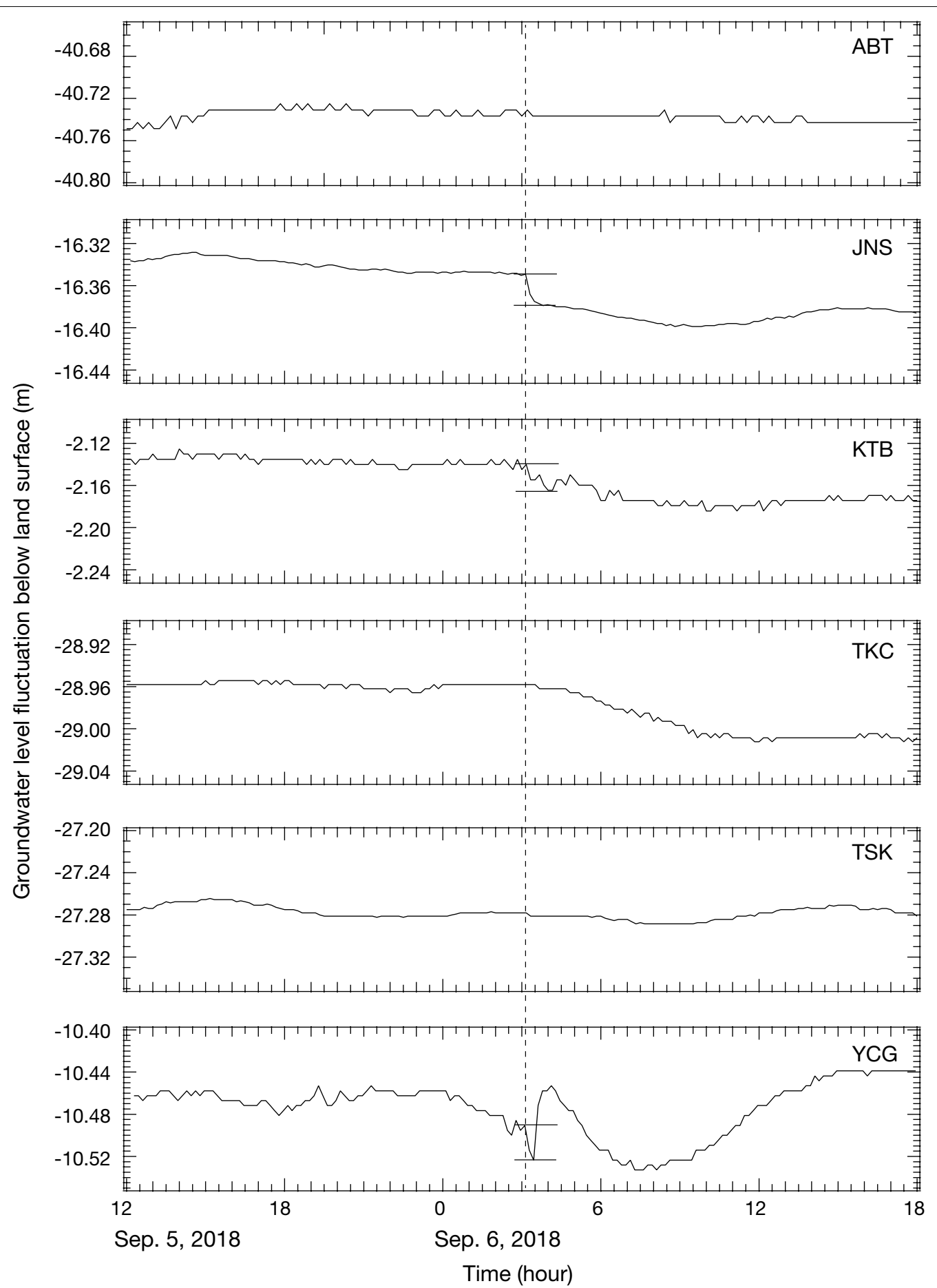

Fig. 3 Observed groundwater levels in the monitored observation wells at 10-min intervals. The step-like decreases, which are highlighted between two horizontal lines around the time of the earthquake, are detected in wells JNS, KTB, and YCG. The dotted line indicates the timing of the earthquake 


$$
\frac{\Delta h}{\Delta \varepsilon}=\frac{1}{\rho g} \frac{\Delta p}{\Delta \varepsilon},
$$

where $\Delta p$ is the change in pore pressure of the aquifer, $\rho$ is the density of water, and $g$ is the acceleration of gravity. The right-hand term then becomes:

$$
\frac{\Delta p}{\Delta \varepsilon}=\frac{\Delta \sigma}{\Delta \varepsilon} \frac{\Delta p}{\Delta \sigma},
$$

where $\Delta \sigma$ is the change in stress. If there is no change in water content, $\Delta \sigma / \Delta \varepsilon$ is described as the undrained compressibility, or $1 / \beta_{u}$, and $\Delta p / \Delta \sigma$ is the negative value of the Skempton's coefficient, $-B$. The negative sign means conversion of pore pressure for stress, which means that a pore pressure increase corresponds to a decrease in stress. This latter term can be rewritten using several different compressibility terms (Rice and Cleary 1976; Wang 2000):

$$
\frac{\Delta p}{\Delta \sigma}=-B=-\frac{\beta-\beta_{\mathrm{s}}}{\beta-\beta_{\mathrm{s}}+\varphi\left(\beta_{\mathrm{f}}-\beta_{\phi}\right)},
$$

and Eq. (1) then yields:

$$
\frac{\Delta h}{\Delta \varepsilon}=-\frac{1}{\rho g} \frac{1}{\beta_{\mathrm{u}}} \frac{\beta-\beta_{\mathrm{s}}}{\beta-\beta_{\mathrm{s}}+\varphi\left(\beta_{\mathrm{f}}-\beta_{\varphi}\right)},
$$

where $\phi$ is the porosity, and $\beta, \beta_{\mathrm{s}}, \beta_{\phi}$, and $\beta_{\mathrm{f}}$ are the solid phase, unjacketed, pore, and water compressibility, respectively. The response of groundwater level to volumetric strain can be expressed in terms of porosity and compressibility variations within the aquifer. The response is known to fluctuate over time and with earthquakes or pumping tests (Matsumoto and Roeloffs 2003).

\section{Results and discussion}

Changes in amplitude and phase shifts in response to the $\mathrm{M}_{\mathbf{2}}$ tidal constituent

The observed groundwater level changes have tidal and atmospheric components. The effects of tidal and atmospheric components on the total groundwater level change were estimated and removed using the BAYTAPG tidal analysis software (Tamura et al. 1991). Theoretical volumetric strain at well sites related to tides was estimated using the GOTIC2 software (Matsumoto et al. 2001), and is shown in Table 2. Because the fluctuation in groundwater level is generally proportional to the applied strain of a tidal component, the response of groundwater level to this component is directly related to the poroelastic characteristics of the aquifer (i.e., Jacob 1940; Wang 2000).

The response of groundwater level to the volumetric strain associated with the $\mathrm{M}_{2}$ tidal constituent (period: $12.4206 \mathrm{~h}$ ) was obtained every 31 days, from September 2017 to December 2018, using the BAYTAP-G software. The average amplitude and phase at the six wells were also estimated (Table 2). The negative phase shifts denote a lag behind the equilibrium tide estimated by GOTIC2. Figure 4 shows the $\mathrm{M}_{2}$ amplitude changes and phase shifts with respect to the $M_{2}$ constituent phase in GOTIC2 data at the six wells. The phase shift errors of well ABT are greater than those of the other wells, because of the shallow depth of the well. Well YCG is as shallow as ABT, but the well taps thermal water, which seems to rise from deeper aquifers (Okamoto et al. 1957). Here, the reference phase of the ocean tide for well YCG was used, because the phase is close to the ocean tide and well YCG is surrounded by the sea. In general, seismic waves often change the permeability and the amplitude responses and phase shifts for tidal components (Matsumoto and Roeloffs 2003; Elkhoury et al. 2006; Kinoshita et al. 2015). However, the $M_{2}$

\begin{tabular}{|c|c|c|c|c|c|c|c|c|}
\hline & Equilibrium & & Oceanic tide & & Total & & Average valı & ff water level \\
\hline & Amp. $\left(10^{-9}\right)$ & Phase $\left({ }^{\circ}\right)$ & Amp. $\left(10^{-9}\right)$ & Phase $\left({ }^{\circ}\right)$ & Amp. $\left(10^{-9}\right)$ & Phase $\left({ }^{\circ}\right)$ & Amp. $(\mathrm{mm})$ & Phase $\left({ }^{\circ}\right)$ \\
\hline $\mathrm{ABT}$ & 9.84 & 0.0 & 4.21 & -99.5 & 10.05 & -24.4 & $0.84 \pm 0.14$ & $-31.0 \pm 9.8$ \\
\hline JNS & 10.01 & 0.0 & 3.47 & -99.2 & 10.06 & -19.9 & $5.02 \pm 0.08$ & $-25.0 \pm 1.0$ \\
\hline KTB & 10.00 & 0.0 & 3.73 & -99.7 & 10.07 & -21.4 & $3.07 \pm 0.14$ & $-23.8 \pm 2.6$ \\
\hline TKC & 9.54 & 0.0 & 1.72 & -91.5 & 9.65 & -10.3 & $4.97 \pm 0.12$ & $-44.3 \pm 1.4$ \\
\hline TSK & 9.53 & 0.0 & 2.03 & -94.5 & 9.59 & -12.2 & $3.99 \pm 0.07$ & $-11.5 \pm 1.0$ \\
\hline YCG & 10.09 & 0.0 & 2.48 & -97.2 & 10.08 & -14.1 & $26.88 \pm 0.19$ & $-117.0 \pm 0.4$ \\
\hline
\end{tabular}

Table 2 Theoretical amplitudes and phase shifts of the $M_{2}$ tidal constituent used to estimated volumetric strain, equilibrium tide, oceanic tide loading effect, and total tidal strain, calculated using GOTIC2, and average responses in observed groundwater level, calculated using BAYTAP-G

Negative phase shifts correspond to lags behind the equilibrium tide 


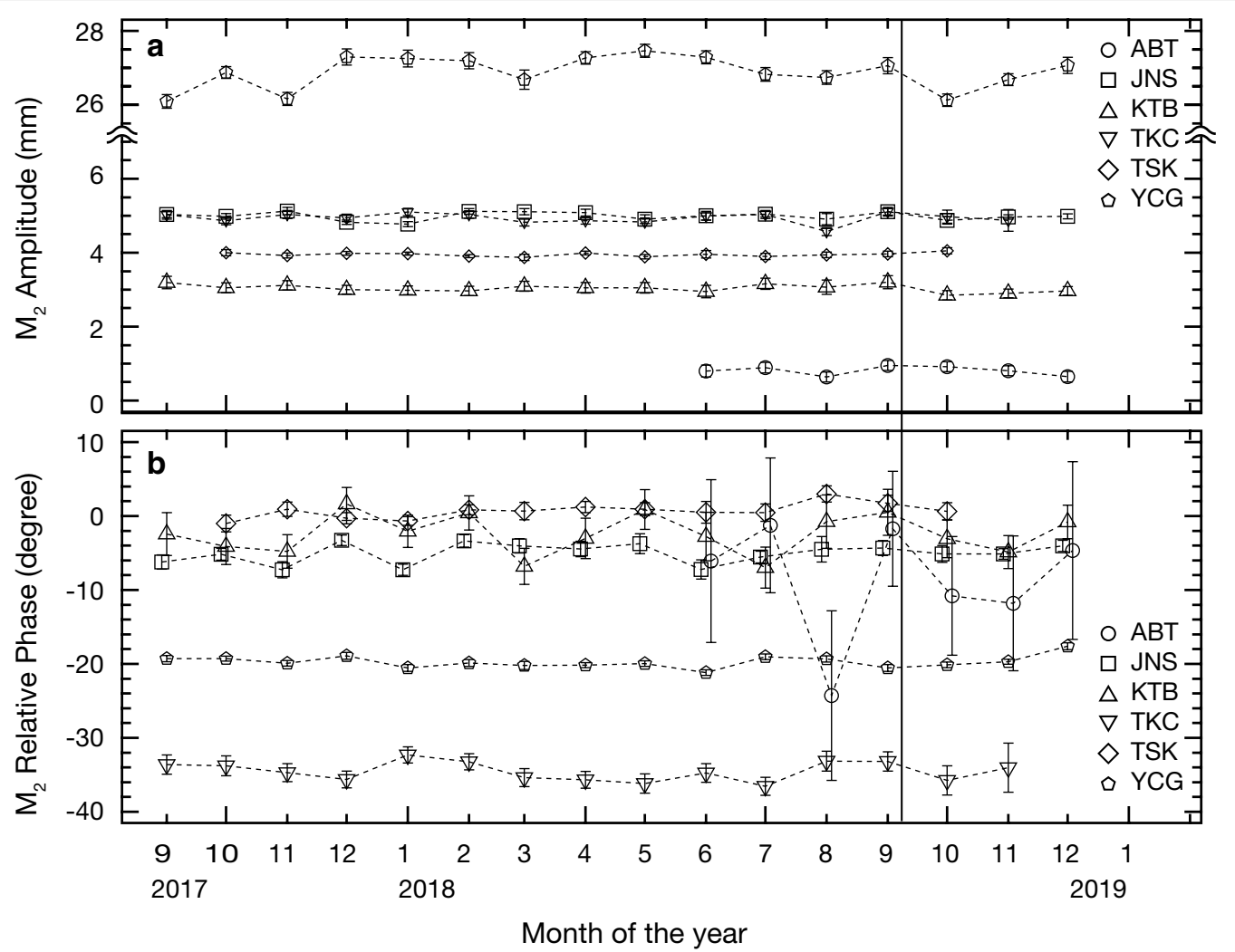

Fig. 4 Amplitude responses and phase shifts of the $M_{2}$ tidal constituent (period: $12.4206 \mathrm{~h}$ ) with respect to the phase in the GOTIC2 data between September 2017 and October 2018. Error bars are one sigma. The responses were calculated every 31 days using the BAYTAP-G tidal analysis software. The solid line indicates the timing of the earthquake

Table 3 Observed coseismic change (OCC) of groundwater level, groundwater response to the $M_{2}$ tidal component, volumetric strain (CVS) calculated using the code of Okada (1992), and expected coseismic change (ECC) in groundwater level

\begin{tabular}{lllll}
\hline Site & OCC $(\mathbf{c m})$ & $\begin{array}{l}\text { Response for } \mathbf{M}_{\mathbf{2}} \\
\text { tide }\left(\mathbf{m m} / \mathbf{1 0}^{-\mathbf{9}}\right. \\
\text { strain) }\end{array}$ & $\begin{array}{l}\text { CVS }\left(\times \mathbf{1 0}^{-\mathbf{8}}\right. \\
\text { strain) }\end{array}$ & ECC (cm) \\
\hline ABT & n.d. & $0.08 \pm 0.01$ & 4.4 & -0.4 \\
JNS & -3.5 & $0.50 \pm 0.01$ & 1.5 & -0.8 \\
KTB & -3.0 & $0.30 \pm 0.01$ & 2.1 & -0.6 \\
TKC & n.d. & $0.52 \pm 0.01$ & 0.41 & -0.2 \\
TSK & n.d. & $0.42 \pm 0.01$ & 0.23 & -0.1 \\
YCG & -3.3 & $2.67 \pm 0.02$ & 1.4 & -3.8 \\
\hline
\end{tabular}

n.d. Coseismic change in groundwater level is not detected

amplitudes have errors with $0.07-0.19 \mathrm{~mm}$ (Table 2), and although the phases at the wells show some variation, they are almost constant over the period considered. Therefore, they do not change prior and after the earthquake.

\section{Coseismic changes in groundwater level}

Coseismic changes in groundwater heads have been extensively studied elsewhere (i.e., Roeloffs 1996; Quilty and Roeloffs 1997; Akita and Matsumoto 2001, 2004; Kitagawa et al. 2006; Kinoshita et al. 2015). These changes are occasionally recognized as reflecting the poroelastic response to the seismic events, but do not correlate with the coseismic volumetric strain changes in many cases (Koizumi et al. 1996; Itaba et al. 2008; Shi et al. 2015). Table 3 lists the observed coseismic changes (OCC), the responses to the $\mathrm{M}_{2}$ tidal constituent, calculated volumetric strain (CVS), and expected coseismic change from the volumetric strain (ECC). We observed step-like decreases in groundwater levels, of between 3.0 and $3.5 \mathrm{~cm}$, in wells JNS, $\mathrm{KTB}$, and YCG, but no change in groundwater level was detected in the other wells (Fig. 3, Table 3). The observed coseismic change in well YCG is similar to the estimated coseismic change determined using the corresponding responses to the $\mathrm{M}_{2}$ tidal constituent 
Table 4 Comparison of coseismic changes between the 2003 Tokachi-Oki, the 2004 Kushiro-Oki, and the 2018 Hokkaido Eastern Iburi earthquake

\begin{tabular}{|c|c|c|c|c|c|c|c|c|c|}
\hline \multirow[t]{2}{*}{ Site } & \multicolumn{3}{|c|}{ Tokachi-Oki Eq. (2003) } & \multicolumn{3}{|c|}{ Kushiro-Oki Eq. (2004) } & \multicolumn{3}{|c|}{ Eastern Iburi Eq. (2018) } \\
\hline & $\mathrm{OCC}(\mathrm{cm})$ & $\mathrm{ECC}(\mathrm{cm})$ & OCC/ECC & OCC $(\mathrm{cm})$ & $\mathrm{ECC}(\mathrm{cm})$ & OCC/ECC & $\mathrm{OCC}(\mathrm{cm})$ & $\mathrm{ECC}(\mathrm{cm})$ & OCC/ECC \\
\hline $\mathrm{ABT}$ & -59 & -12.6 & 4.6 & -35 & -0.1 & 350 & n.d. & -0.4 & n.d. \\
\hline JNS & -22 & -9.9 & 2.2 & n.d. & n.d. & n.d. & -3.5 & -0.8 & 4.4 \\
\hline KTB & -5 & -6.7 & 0.7 & 0 & 0.1 & 0.0 & -3.0 & -0.6 & 5.0 \\
\hline TKC & n.d. & n.d. & n.d. & n.d. & n.d. & n.d. & n.d. & -0.2 & n.d. \\
\hline TSK & n.d. & n.d. & n.d. & n.d. & n.d. & n.d. & n.d. & -0.1 & n.d. \\
\hline YCG & 10 & -31.5 & -0.3 & 0 & 0.1 & 0.0 & -3.3 & -3.8 & 0.9 \\
\hline
\end{tabular}

Observed coseismic change (OCC) of groundwater level and expected coseismic change (ECC) in groundwater level from the $\mathrm{M}_{2}$ tidal component n.d. no data. The data of the Tokachi-Oki and Kushiro-Oki earthquakes are from Akita and Matsumoto (2004) and Shibata et al. (2010)

component and calculated volumetric strain $(-3.3$ vs. -3.8 ; Table 3 ), but there is a large undulation in groundwater level at this well after the coseismic change (Fig. 3). There are several wells tapping thermal water close to well YCG, which are accompanied by $\mathrm{CO}_{2}$ gas emissions (Okamoto et al. 1957). The large undulation after the coseismic change could be due to the presence of gas in groundwater. The observed coseismic change of wells JNS and KTB are 4.4 and 5.0 times larger than the corresponding estimated changes, respectively (Table 4 ).

Coseismic changes associated with past seismic events are also reported for wells ABT, JNS, KTB, and YCG, and related to the 2003 Tokachi-Oki and the 2004 KushiroOki earthquakes (Akita and Matsumoto 2004; Shibata et al. 2010). These past coseismic changes can be compared with those related to the 2018 Hokkaido Eastern Iburi earthquake (Table 4). Table 4 shows the observed coseismic changes (OCC), the expected coseismic changes (ECC) calculated using the responses to the $M_{2}$ tidal constituent component and the calculated volumetric strain, and the ratios of OCC to ECC for each earthquake at each well. The ratios are found to be quite different for the different earthquakes for a given well, complicating our understanding. Finding universal explanations for coseismic change is already a well-known challenge, because earthquake-related fluctuations in groundwater heads can be caused by various factors (Koizumi 2013), and local changes occur independently of the change in crustal strain (Kitagawa et al. 2006). The obtained result also suggests that, even within the same well, the coseismic response of groundwater level is different for each earthquake. The different observed earthquake-related groundwater level changes at the same well have been reported by King et al. (1999), who suggested that the sensitivity to seismic shaking appears to be variable. Although the cause of the difference is still unclear, the compilation of such evidence can improve the understanding of coseismic changes in groundwater.

\section{Conclusions}

Groundwater levels were monitored in six observation wells in Hokkaido, Japan, which have not been in use in the past 20 years. During the 2018 Hokkaido Eastern Iburi earthquake (M6.7), a coseismic decrease in groundwater level was observed in three of the wells (JNS, KTB, and YCG). We analyzed their amplitude responses and phase shifts in groundwater level related to the $\mathrm{M}_{2}$ tidal constituent. Changes in amplitude responses and phase shifts of the three wells show very little variation and are within the variation. Although observed coseismic change was found to be explained by the response to the $\mathrm{M}_{2}$ tidal constituent and calculated volumetric strain in one instance (well YCG), for the other two cases (wells JNS and KTB) observed changes are 4.4 and 5.0 times higher than the estimated changes, respectively. Even within the same well, coseismic changes are found to be different for different earthquake events.

\footnotetext{
Acknowledgements

We gratefully thank the editor and anonymous reviewers for their constructive and helpful comments. We also thank Dr. S. Palmer (Université de Nantes) for her comments to improve the manuscript. Drs. N. Okazaki, T. Suzuki, and M. Tamura (Geological Survey of Hokkaido) provided continual support of groundwater level measurement at the wells. We used the software package GMT (Wessel and Smith 1998) to illustrate the figures. This work was supported by JSPS/MEXT KAKENHI Grant Numbers 18K19952 and 18K18777.

\section{Authors' contributions}

TS analyzed the data with help from RT, and designed the research. HT and TK contributed to the discussion of the relationship between strain fields and groundwater-level changes. NT, YS, and DLP acquired data. All authors read and approved the final manuscript.
} 


\section{Funding}

This work was supported by JSPS/MEXT KAKENHI Grant Numbers 18 K19952 and $18 \mathrm{~K} 18777$

\section{Availability of data and materials}

Data are present in supporting files. Other data are also available from TS and RT upon request.

\section{Ethics approval and consent to participate}

Not applicable.

\section{Consent for publication}

Not applicable.

\section{Competing interests}

The authors declare that they have no competing interests.

\begin{abstract}
Author details
${ }^{1}$ Institute for Geothermal Sciences, Graduate School of Science, Kyoto University, Noguchibaru 3088, Beppu, Oita 874-0903, Japan. ${ }^{2}$ Geological Survey of Hokkaido, Hokkaido Research Organization, N19 W12, Kita-ku, Sapporo 060-0819, Japan. ${ }^{3}$ Institute of Seismology and Volcanology, Hokkaido University, N10 W8, Kita-ku, Sapporo 060-0810, Japan. ${ }^{4}$ Atmosphere and Ocean Research Institute, The University of Tokyo, Kashiwa, Chiba 277-8564, Japan. ${ }^{5}$ GEOTOP Research Center on the Dynamics of the Earth System, Université du Québec à Montréal, Montréal, QC H3X 3Y7, Canada.
\end{abstract}

\section{Received: 24 May 2019 Accepted: 17 February 2020}

Published online: 26 February 2020

\section{References}

Akita F, Matsumoto N (2001) Coseismic groundwater level changes in hot spring wells in Hokkaido induced by four earthquakes larger than M7.5 between 1993 and 1994. J Seismol Soc Jpn 53:193-204 (in Japanese with English abstract)

Akita F, Matsumoto N (2004) Hydrological responses induces by the Tokachioki earthquake in 2003 at hot spring wells in Hokkaido, Japan. Geophys Res Lett 31:L16603. https://doi.org/10.1029/2004GL020433

Brodsky EE, Roeloffs EA, Woodcock D, Gall I, Manga M (2003) A mechanism for sustained groundwater pressure changes induced by distant earthquakes. J Geophys Res. https://doi.org/10.1029/2002JB002321

Elkhoury JE, Brodsky EE, Agnew DC (2006) Seismic waves increase permeability. Nature 441:1135-1138. https://doi.org/10.1038/nature04798

Geospatial Information Authority of Japan (2018) The 2018 Hokkaido Eastern Iburi earthquake: fault model (preliminary). http://www.gsi.go.jp/cais/ topic180912-index.html. Accessed 30 Jan 2019

Hsieh S, Bredehoef JD, Farr JM (1987) Determination of aquifer transmissivity from earth tide analysis. Water Resour Res 23:1824-1832

Igarashi G, Wakita H (1991) Tidal responses and earthquake-related changes in the water level of deep wells. J Geophys Res 96:4269-4278

Itaba S, Koizumi N, Matsumoto N, Takahashi M, Sato T, Ohtani R, Kitagawa Y, Kuwahara Y, Sato T, Ozawa K (2008) Groundwater level changes related to the ground shaking of the Noto Hanto earthquake in 2007. Earth Planets Space 60:1153-1159. https://doi.org/10.1186/BF03352872

Jacob CE (1940) On the flow water in an elastic artesian aquifer. Trans Am Geophys Union 22:783-787

Japan Meteorological Agency (2018a) The 2018 Hokkaido Eastern Iburi earthquake. https://www.static.jishin.go.jp/resource/monthly/2018/20180 906_iburi.pdf. Accessed 30 Jan 2019

Japan Meteorological Agency (2018b) AMeDAS (Automated Meteorological Data Acquisition System). http://www.data.jma.go.jp/obd/stats/etrn/ index.php. Accessed 22 Nov 2019

King CY, Azuma S, Igarashi G, Ohno M, Saito H, Wakita H (1999) Earthquakerelated water-level changes 16 closely clustered wells in Tono, central Japan. J Geophys Res 104:13073-13082

Kinoshita C, Kano Y, Ito H (2015) Shallow crustal permeability enhancement in central Japan due to the 2011 Tohoku earthquake. Geophys Res Lett 42:773-780. https://doi.org/10.1002/2014GL062792
Kitagawa Y, Koizumi N, Takahashi M, Matsumoto N, Sato T (2006) Changes in groundwater levels or pressures associated with the 2004 earthquake off the west coast of northern Sumatra (M9.0). Earth Planets Space 58:173-179. https://doi.org/10.1186/BF03353375

Koizumi N (2013) Coseismic and postseismic groundwater pressure changes. J Geogr 122:159-169

Koizumi N, Kano Y, Kitagawa Y, Sato T, Takahashi M, Nishimura S, Nishida R (1996) Groundwater anomalies associated with the 1995 Hyogo-ken Nanbu earthquake. J Phys Earth 44:373-380

Koizumi N, Kitagawa Y, Takahashi M, Sato T, Matsumoto N, Ito H, Kuwahara Y, Cho A, Sato T (2002) Changes in groundwater level and crustal strain in and around the Kinki district related to the 2001 Geiyo earthquake. J Seismol Soc Jpn 55:119-127

Manga M, Wang CY (2007) Earthquake hydrology. In: Schubert G (ed) Treatise on geophysics, vol 4. Elsevier, Amsterdam, pp 293-320

Matsumoto N, Roeloffs EA (2003) Hydrological response to earthquakes in the Haibara well, central Japan-II. Possible mechanism inferred from timevarying hydraulic properties. Geophys J Int 155:899-913

Matsumoto K, Sato T, Takanezawa T, Ooe M (2001) GOTIC2: a program for computation of oceanic tidal loading effect. J Geod Soc Jpn 47:243-248

Montgomery DR, Manga M (2003) Streamflow and water well responses to earthquakes. Science 300(5628):2047-2049. https://doi.org/10.1126/scien ce. 1082980

Muir-Wood R, King GCP (1993) Hydrological signatures of earthquake strain. J Geophys Res Solid Earth 98(B12):22035-22068

Okada Y (1992) Internal deformation due to shear and tensile faults in a halfspace. Bull Seismol Soc Am 82:1018-1040

Okamoto G, Kubota H, Nagayama S, Irie F, Kato T (1957) Experimental study of corrosion prevention for the casing at Yachigashira hot-spring. Corros Eng Dis 3:231-232

Quilty E, Roeloffs EA (1997) Water level changes in response to the December 20, 1994 M4.7 earthquake near Parkfield, California. Bull Seismol Soc Am $87: 310-317$

Rice JR, Cleary MP (1976) Some basic stress diffusion solutions for fluid saturated elastic porous media with compressible constituents. Rev Geophys Space Phys 14:227-241

Roeloffs EA (1996) Poroelastic techniques in the study of earthquake-related hydrologic phenomena. In: Dmowska R (ed) Advances in geophysics, vol 34. Academic, San Diego, pp 135-195

Rojstaczer S, Wolf S, Michel R (1995) Permeability enhancement in the shallow crust as a cause of earthquake-induced hydrological processes. Nature 373:237-239. https://doi.org/10.1038/373237a0

Shi Z, Wang G, Manga M, Wang CY (2015) Permeability changes after large earthquakes: insights from co-seismic water level changes throughout China in response to four $\mathrm{M}>8$ earthquakes. Earth Planet Sci Lett 430:66-74

Shibata T, Matsumoto N, Akita F, Okazaki N, Takahashi H, Ikeda R (2010) Linear poroelasticity of groundwater levels from observational records at wells in Hokkaido, Japan. Tectonophysics 483:305-309

Sibson RH, Rowland JV (2003) Stress, fluid pressure and structural permeability in seismogenic crust, North Island, New Zealand. Geophys J Int 154(2):584-594

Takahashi H, Kimura R (2019) The 2018 Hokkaido Eastern Iburi earthquake and its aftermath. J Disaster Res 14:sc20190112

Tamura Y, Sato T, Ooe M, Ishiguro M (1991) A procedure for tidal analysis with a Bayesian information criterion. Geophys J Int 104:507-516

Wakita H (1975) Water wells as possible indicators of tectonics strain. Science 189:553-555

Wang HF (2000) Theory of linear poroelasticity with applications to geomechanics and hydrogeology. Princeton Univ. Press, Princeton

Wang CY, Wang CH, Manga M (2004) Coseismic release of water from mountains: evidence from the 1999 (Mw. 7.5) Chi-Chi earthquake. Geology 32(9):769-772

Wessel P, Smith WHF (1998) New, improved version of the Generic Mapping Tools released. EOS Trans AGU 79:579

\section{Publisher's Note}

Springer Nature remains neutral with regard to jurisdictional claims in published maps and institutional affiliations. 